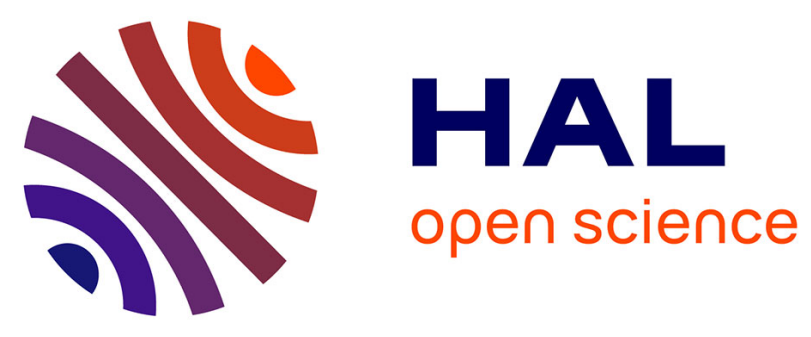

\title{
Bacterial host and reporter gene optimization for genetically encoded whole cell biosensors
}

Catherine Brutesco, Sandra Preveral, Camille Escoffier, Elodie C. T.

Descamps, Elsa Prudent, Julien Cayron, Louis Dumas, Manon Ricquebourg, Géraldine Adryanczyk-Perrier, Arjan de Groot, et al.

\section{To cite this version:}

Catherine Brutesco, Sandra Preveral, Camille Escoffier, Elodie C. T. Descamps, Elsa Prudent, et al.. Bacterial host and reporter gene optimization for genetically encoded whole cell biosensors. Environmental Science and Pollution Research, 2017, 24 (1), pp.52-65. 10.1007/s11356-016-6952-2 . hal-01640038

\section{HAL Id: hal-01640038 \\ https://hal.science/hal-01640038}

Submitted on 23 Apr 2018

HAL is a multi-disciplinary open access archive for the deposit and dissemination of scientific research documents, whether they are published or not. The documents may come from teaching and research institutions in France or abroad, or from public or private research centers.
L'archive ouverte pluridisciplinaire HAL, est destinée au dépôt et à la diffusion de documents scientifiques de niveau recherche, publiés ou non, émanant des établissements d'enseignement et de recherche français ou étrangers, des laboratoires publics ou privés. 


\title{
Bacterial host and reporter gene optimization for genetically encoded whole cell biosensors
}

Catherine Brutesco ${ }^{1,2,3}$, Sandra Prévéral ${ }^{1,2,3}$, Camille Escoffier ${ }^{1,2,3}$, Elodie C. T. Descamps ${ }^{1,2,3}$, Elsa Prudent ${ }^{4,5,6}$, Julien Cayron 4,5,6, Louis Dumas 1,2,3, Manon Ricquebourg 1,2,3,

Géraldine Adryanczyk-Perrier ${ }^{1,2,3}$, Arjan de Groot ${ }^{1,2,3}$, Daniel Garcia ${ }^{1,2,3}$, Agnès Rodrigue ${ }^{4,5,6}$, David Pignol ${ }^{1,2,3}$, Nicolas Ginet $1,2,3$

1 CEA, DRF, BIAM, Lab Bioenerget Cellulaire Saint-Paul-lez-Durance France

2 2.CNRS, UMR Biol Veget and Microbiol Environ Saint-Paul-lez-Durance France

3 3.Aix-Marseille Université Saint-Paul-lez-Durance France

4 4.Université de Lyon Lyon France

5 5.INSA de Lyon Villeurbanne France

6 6.CNRS, UMR5240, Microbiologie, Adaptation et Pathogénie Villeurbanne France

\begin{abstract}
Whole-cell biosensors based on reporter genes allow detection of toxic metals in water with high selectivity and sensitivity under laboratory conditions; nevertheless, their transfer to a commercial inline water analyzer requires specific adaptation and optimization to field conditions as well as economical considerations. We focused here on both the influence of the bacterial host and the choice of the reporter gene by following the responses of global toxicity biosensors based on constitutive bacterial promoters as well as arsenite biosensors based on the arsenite-inducible $\mathrm{P}_{\text {ars }}$ promoter. We observed important variations of the bioluminescence emission levels in five different Escherichia coli strains harboring two different lux-based biosensors, suggesting that the best host strain has to be empirically selected for each new biosensor under construction. We also investigated the bioluminescence reporter gene system transferred into Deinococcus deserti, an environmental, desiccation- and radiation-tolerant bacterium that would reduce the manufacturing costs of bacterial biosensors for commercial water analyzers and open the field of biodetection in radioactive environments. We thus successfully obtained a cell survival biosensor and a metal biosensor able to detect a concentration as low as $100 \mathrm{nM}$ of arsenite in $D$. deserti. We demonstrated that the arsenite biosensor resisted desiccation and remained functional after 7 days stored in air-dried $D$. deserti cells. We also report here the use of a new near-infrared (NIR) fluorescent reporter candidate, a bacteriophytochrome from the magnetotactic bacterium Magnetospirillum magneticum AMB-1, which showed a NIR fluorescent signal that remained optimal despite increasing sample turbidity, while in similar conditions, a drastic loss of the lux-based biosensors signal was observed.
\end{abstract}

\section{Keywords}

Arsenite biosensor Bioluminescence Near-infrared fluorescent reporter Deinococcus deserti Desiccation Bacteriophytochrome

Catherine Brutesco, Sandra Prévéral and Camille Escoffier contributed equally to this work.

\section{Introduction}

An efficient surveillance of water networks requires automatic monitoring systems able to quickly raise the alarm in the event of an accidental or intentional pollution, reducing the risk of downstream contaminations with appropriate measures implemented as soon as possible. In this context, whole-cell biosensors offer sensitive and rapid alert systems for metal detection that can be integrated into inline water monitoring devices. These biological sensors are not intended to fully replace conventional analytical methods, but they offer the possibility to rapidly alarm the end-user in case of global or specific toxicities affecting the water network and take proper actions 
before conventional analyses are made for confirmation. Whole-cell biosensors are based on engineered bacteria genetically transformed with reporter genes whose expression is driven by an inducible promoter; the selected promoter in its native genetic context is involved in the intracellular mechanism of metal resistance (Magrisso et al. 2008; Hynninen and Virta 2010). Typically, the interaction between the metal and a specific repressor protein, otherwise bound to the promoter region on the DNA sequence, results in the release of the repressor from the promoting region, allowing transcription of the reporter gene and detection of the presence or activity of the gene product. Thanks to this genetic modification, these bacterial biosensors are able to emit a semi-quantitative signal in the presence of targeted metals (Xu et al. 2013). Signal transduction by light emission (e.g., bioluminescence or fluorescence) is very popular due to its sensitivity and the variety of reporter genes available (Xiong et al. 2012). Among them, bacterial luciferase (encoded in the lux operon) is particularly well suited for the development of autonomous bacterial biosensors as the genes required for the production of the substrate for luciferase can be genetically co-introduced (Prévéral et al. 2016) (this special issue). Extensive searches for different promoters regulated by various metallic targets have been well documented in the literature (Sun et al. 2015); efforts to improve the dose-responses and the specificity by genetic modifications of the regulators have also been described (Peng et al. 2010), and an example is presented in this special issue for a nickel bioluminescent biosensor (Cayron et al. 2015).

Transferring light-emitting bacterial biosensors from the laboratory to on-field water analysis systems requires several optimizations, not all relying on biological research but also including technical or economical considerations. For a given host bacterial species, the genetic background is liable to affect the functioning of the biosensor at various stages, such as intracellular metal concentration, transcription efficiency of the reporter gene as well as the reporter protein expression, folding, and maturation; the integration of these various biological processes affect the biosensor global response in terms of sensitivity, specificity, or time response (Yagur-Kroll and Belkin 2014). In the case of bacterial luciferase, the genetic background may also affect the intracellular production of the luciferase substrate (an aldehyde) as it can also be genetically encoded. Thanks to countless studies and genetic tools available, Escherichia coli laboratory strains can conveniently host biosensors based on the reporter gene system but the selection of the proper host strain is critical. Whereas a light-emitting reporter gene system such as the bacterial luciferase can function perfectly well in laboratory conditions on idealized water samples, measurements on real samples taken from ground waters, drainage, industrial effluents, or sewage can be tampered by absorbing and fluorescent materials or particles in suspension. In such cases, it could be wise to use near-infrared (NIR) light as a detectable signal: in this spectral region, light is less absorbed by organic molecules, more penetrating and less prone to diffusion. NIR-fluorescent reporters derived from bacteriophytochromes - biological light switches - have been efficiently engineered by Shu et al. to the purpose of in vivo, non-invasive light imaging where NIR light can be detected through the living tissues (Shu et al. 2009). Such reporters could be useful when the complexity of the environmental matrix prevents an efficient collection of light emitted by whole-cell biosensors usually operating in the visible light spectrum.

The results presented here were obtained during a 4-year translational project called COMBITOX funded by the French Agence Nationale pour la Recherche (ANR). This collaborative project, described in the Editorial of this special issue (Ansaldi et al. 2015), aimed at designing and building a prototype of semi-autonomous inline water analyzer including biosensors to detect pathogenic bacteria with bacteriophages, toxic metals with whole-cell biosensors and environmental toxins with antibodies. Regarding the whole-cell biosensors module, we emphasized in another paper in this special issue on the necessity to develop suitable conservation systems for their integration as bioreagents into a technical device aimed at water analysis (Prévéral et al. 2016); the main challenge here consists in maintaining acceptable performances for the bioreagent in the apparatus compared to the laboratory conditions. We showed that such biosensors can be conditioned by lyophilization for the intended usage, but this technique represents an additional cost in the production process. Unfortunately, a more simple and costeffective solution such as desiccation proved to be unreliable in our case, probably due to the 
difficulty for E. coli to recover from the stressinduced by desiccation. In addition to their intrinsic properties (specificity, sensitivity, time response, reliability), bacterial biosensors for inline water analysis must remain economically competitive with other techniques and this consideration prompted us to probe other microorganisms more amenable to simple conservation techniques such as desiccation.

In this context, we investigate here the response of our biosensors in different strains of $E$. coliin an attempt to identify an optimal strain to host luciferase reporters. We also report here the use of a new NIR fluorescent reporter candidate, a bacteriophytochrome from the magnetotactic bacterium Magnetospirillum magneticum AMB-1 that could circumvent the adverse effects of the complexity of environmental water samples on light detection. Lastly, with the objective of simplifying the conservation of the biosensors, we also investigate the transfer of the bioluminescence reporter gene system in Deinococcus deserti, a bacterium isolated from the desert and more amenable than are laboratory E. coli strains to desiccation.

\section{Material and methods}

Strains, plasmids, and primers

Escherichia coli strains used in this study are W3110 (Hayashi et al. 2006), TD2158 (Vinay et al. 2015). and Life Technologies-branded Dh10beta, TOP10 and BL21. D. deserti RD19 strain, a streptomycin-resistant mutant of wild-type strain VCD115 (de Groot et al. 2005; Dulermo et al. 2009), was used for desiccation experiments. In this article, when we refer to the L-arabinoseinducible $\mathrm{P}_{\mathrm{BAD}}$, arsenite-inducible $\mathrm{P}_{\mathrm{ars}}$ and mercury-inducible $\mathrm{P}_{\text {mer }}$ promoters, the corresponding DNA sequences systematically include respectively the $\operatorname{ara} C$, $\operatorname{ars} R$, and merRgenes encoding the regulatory proteins. The plasmids pRpod-lux, pMer-lux, and pArs-lux cited in this article have been described in this special issue (Prévéral et al. 2016). The vectors and the PCR primers used here are described in Tables $\underline{1}$ and $\underline{2}$, respectively. The host/vector combinations are listed in Table $\underline{3}$.

Table 1

Plasmids used in this study

\begin{tabular}{|c|c|c|}
\hline Plasmid name & Features & Reference \\
\hline рРФ3295 & $\begin{array}{l}\text { Transcriptional fusion between L- } \\
\text { arabinose-inducible } \mathrm{P}_{\mathrm{BADp}} \text {-omoter } \\
\text { and Rhodopseudomonas } \\
\text { palustris apo-bacteriophytochrome } \\
\text { gene }+ \text { hmuO (heme oxygenase), } \\
{\left[\text { Amp }{ }^{\mathrm{R}}\right]}\end{array}$ & $\begin{array}{l}\text { Giraud and } \\
\text { Verméglio } \\
(\underline{2008)})\end{array}$ \\
\hline pMagBphP & $\begin{array}{l}\text { Transcriptional fusion between L- } \\
\text { arabinose-inducible PBADpromoter } \\
\text { and magBphP (apo- } \\
\text { bacteriophytochrome) }+h m u O(\text { heme } \\
\text { oxygenase), }\left[\mathrm{Amp}^{\mathrm{R}}\right]\end{array}$ & This study \\
\hline pArs-lux & $\begin{array}{l}\text { Transcriptional fusion between } \\
\text { arsenite-inducible } \mathrm{P}_{\text {ars }} \text { promoter } \\
\text { and } l u x C D A B E(\text { bacterial } \\
\text { luciferase), }\left[\mathrm{Amp}^{\mathrm{R}}\right]\end{array}$ & $\begin{array}{l}\text { Prévéral et al. } \\
\qquad \underline{2016})\end{array}$ \\
\hline pRpoD-lux & $\begin{array}{l}\text { Transcriptional fusion between } \\
\text { constitutive } \mathrm{P}_{\mathrm{rpoD}} \text { promoter } \\
\text { and } l u x C D A B E,\left[\mathrm{Kan}^{\mathrm{R}}\right]\end{array}$ & $\begin{array}{l}\text { Prévéral et al. } \\
\text { (2016) }\end{array}$ \\
\hline
\end{tabular}




\begin{tabular}{|c|c|c|}
\hline Plasmid name & Features & Reference \\
\hline pAAM & $\begin{array}{l}\text { Transcriptional fusion between L- } \\
\text { arabinose-inducible } \mathrm{P}_{\mathrm{BAD}} \text { promoter } \\
\text { and } \operatorname{magBphP},\left[\mathrm{Tet}^{\mathrm{R}}\right]\end{array}$ & This study \\
\hline pBMH & $\begin{array}{l}\text { Transcriptional fusion between } \\
\text { mercury-inducible } \mathrm{P}_{\text {mer }} \text { promoter } \\
\text { and } h m u O,\left[\mathrm{Amp}^{\mathrm{R}}\right]\end{array}$ & This study \\
\hline $\mathrm{pBAH}$ & $\begin{array}{l}\text { Transcriptional fusion between } \\
\text { arsenite-inducible } \mathrm{P}_{\text {ars }} \text { promoter } \\
\text { and } h m u O,\left[\mathrm{Amp}^{\mathrm{R}}\right]\end{array}$ & This study \\
\hline pALT & $\begin{array}{l}\text { Insertion in } D \text {. deserti amyE of the } \\
\text { promoter- } \\
\text { less } \operatorname{lux} C D A B E+\text { translational } \\
\text { fusion } \mathrm{P}_{\text {tuf }}: \mathrm{kan} \text {; replicates in } E \text {. } \\
\text { coli }[\mathrm{AmpR} \text { ] but not in } D . \\
\text { deserti }\left[\mathrm{Kan}^{\mathrm{R}} \text { after integration in }\right. \\
\text { chromosome] }\end{array}$ & This study \\
\hline pAGLT & $\begin{array}{l}\text { In pALT, transcriptional fusion } \\
\text { between the constitutive } \\
\mathrm{P}_{\text {gapdhpromoter and luxCDABE, }} \\
\text { [in } D . \text { deserti } \mathrm{Kan}^{\mathrm{R}} \text {, in } E . \\
\text { coli } \mathrm{Amp}^{\mathrm{R}} \text { ] }\end{array}$ & This study \\
\hline pAALT & $\begin{array}{l}\text { In pALT, transcriptional fusion } \\
\text { between the arsenite-inducible } \\
\mathrm{P}_{\text {ars }} \text { promoter and luxCDABE, [in } D . \\
\text { deserti } \mathrm{Kan}^{\mathrm{R}} \text {, in } E \text {. coliAmp }{ }^{\mathrm{R}} \text { ] }\end{array}$ & This study \\
\hline pBSK-lux-Km & $\begin{array}{l}\text { Promoter- } \\
\text { less luxCDABE + translational } \\
\text { fusion between constitutive } \\
\mathrm{P}_{\text {tuf promoter and kanamycin }} \\
\text { resistance gene, [in } E \text {. coli } \mathrm{Amp}^{\mathrm{R}} \text { ] }\end{array}$ & This study \\
\hline pBSK-lux & $\operatorname{lux} C D A B E,\left[\mathrm{Amp}^{\mathrm{R}}\right]$ & This study \\
\hline pSF0kan & $\begin{array}{l}\text { Source of } \mathrm{P}_{\text {tuf }}: \text { kan for } D \text {. deserti: } \\
\text { translational fusion between } \\
\text { constitutive } \mathrm{P}_{\text {tuf }} \text { promoter of } D \text {. } \\
\text { deserti and kanamycin resistance } \\
\text { gene, cloned as BamHI-XbaI } \\
\text { fragment in pUC19, [in } E \text {. } \\
\text { coliAmp }{ }^{\mathrm{R}} \text { ] }\end{array}$ & Laboratory stock \\
\hline UC18-AmyEDD & $\operatorname{amyE}($ amylase $),\left[\mathrm{Amp}^{\mathrm{R}}\right]$ & This study \\
\hline
\end{tabular}


Table 2

Primers used in this study

\begin{tabular}{|c|c|c|}
\hline Primer & Sequence & Description \\
\hline 1 & GAAGATCTATGACAACGCTGTCCATGTTG & $\begin{array}{l}\text { BglII-magBphP } \\
\text { forward }\end{array}$ \\
\hline 2 & CGGAATTCTTATAACCATTGGAGCAATGTG & $\begin{array}{l}\text { EcoRI-magBphP } \\
\text { reverse }\end{array}$ \\
\hline 3 & ACAACGCCCAGATGAGTCTG & amyE forward \\
\hline 4 & ACATCGAGCTCATCTTCGCC & amyE reverse \\
\hline 5 & ATATTCTAGACCGATACCGGCACGGTAG & amyE-XbaI forward \\
\hline 6 & ATATGGGCCCCGTCGAACCATTCGCCCA & amyE-ApaI reverse \\
\hline 7 & CGAATGGTTCGACGGGGCCCCTTGAGAAGCGCGTTGGTG & $\begin{array}{l}\text { InFusion gapdh } \\
\text { forward }\end{array}$ \\
\hline 8 & TTTTTTTAGTCATACGTACATGCTGTGCCTCCAGTCTTG & $\begin{array}{l}\text { InFusion gapdh } \\
\text { reverse }\end{array}$ \\
\hline 9 & CGAATGGTTCGACGGGGCCCTAAACTGCCAGGAATTGGGG & InFusion ars forward \\
\hline 10 & TTTTTTTAGTCATACGTATAGCAATCTAATTTTTACCGGCAG & InFusion ars reverse \\
\hline 11 & TTGCCATACGGAATTCTAATGTGCCTGTCAAATGGAC & InFusion ara forward \\
\hline 12 & TGCTCATCCGGAATTCCTTATAACCATTGGAGCAATGTGT & InFusion ara reverse \\
\hline 13 & CGGCCAGTGAGCGCGCCCATGGTAGGGATTTTTACCG & InFusion mer forward \\
\hline 14 & ATTACGCCAAGCGCGCAATCTTCTCTCATCCGCCAA & InFusion mer reverse \\
\hline 15 & GTATCGATAAGCTTGATATCGAATTCGATTCTAGAAGGAGGTTG & $\begin{array}{l}\text { InFusion hmuO } \\
\text { forward }\end{array}$ \\
\hline 16 & CAACCTCCTTCTAGAATCGAATTCGATATCAAGCTTATCGATAC & $\begin{array}{l}\text { InFusion hmuO } \\
\text { reverse }\end{array}$ \\
\hline
\end{tabular}


Table 3

Host/vector combinations used in this study

\begin{tabular}{|c|c|c|c|c|c|}
\hline Strain & Vector & Promoter & Signal & Description & Figure \\
\hline E. coliTD 2158 & pRpoD-lux & $\mathrm{P}_{\mathrm{rpoD}}$ & Bioluminescence & $\begin{array}{l}\text { Cell survival } \\
\text { biosensor }\end{array}$ & 1 \\
\hline E. coli $\mathrm{W} 3110$ & pRpoD-lux & $\mathrm{P}_{\mathrm{rpoD}}$ & Bioluminescence & $\begin{array}{l}\text { Cell survival } \\
\text { biosensor }\end{array}$ & 1 \\
\hline $\begin{array}{l}\text { E. } \\
\text { coliDH10beta }\end{array}$ & pRpoD-lux & $\mathrm{P}_{\mathrm{rpoD}}$ & Bioluminescence & $\begin{array}{l}\text { Cell survival } \\
\text { biosensor }\end{array}$ & 1 \\
\hline E. coliTOP 10 & pRpoD-lux & $\mathrm{P}_{\mathrm{rpoD}}$ & Bioluminescence & $\begin{array}{l}\text { Cell survival } \\
\text { biosensor }\end{array}$ & 1 \\
\hline E. coli BL21 & pRpoD-lux & $\mathrm{P}_{\mathrm{rpoD}}$ & Bioluminescence & $\begin{array}{l}\text { Cell survival } \\
\text { biosensor }\end{array}$ & 1 \\
\hline E. coliTD 2158 & pArs-lux & Pars & Bioluminescence & Arsenite biosensor & 1,4 \\
\hline E. coli $\mathrm{W} 3110$ & pArs-lux & $\mathrm{P}_{\text {ars }}$ & Bioluminescence & Arsenite biosensor & 1 \\
\hline $\begin{array}{l}\text { E. } \\
\text { coliDH10beta }\end{array}$ & pArs-lux & $\mathrm{P}_{\text {ars }}$ & Bioluminescence & Arsenite biosensor & 1 \\
\hline E. coli $\mathrm{TOP} 10$ & pArs-lux & $P_{\text {ars }}$ & Bioluminescence & Arsenite biosensor & 1 \\
\hline E. coli BL21 & pArs-lux & $P_{\text {ars }}$ & Bioluminescence & Arsenite biosensor & 1 \\
\hline D. desertiRD19 & pALT & None & Bioluminescence & & 2 \\
\hline D. desertiRD19 & pAGLT & $P_{\text {gapdh }}$ & Bioluminescence & $\begin{array}{l}\text { Cell survival } \\
\text { biosensor }\end{array}$ & 2 \\
\hline D. desertiRD19 & pAALT & $\mathrm{P}_{\text {ars }}$ & Bioluminescence & Arsenite biosensor & $3-5$ \\
\hline $\begin{array}{l}\text { E. } \\
\text { coliDH10beta }\end{array}$ & pMagBphP & $\mathrm{P}_{\mathrm{BAD}}$ & $\begin{array}{l}\text { NIR } \\
\text { fluorescence }\end{array}$ & $\begin{array}{l}\text { Cell survival } \\
\text { biosensor }\end{array}$ & 7,8 \\
\hline $\begin{array}{l}\text { E. } \\
\text { coliDH10beta }\end{array}$ & $\mathrm{pBAH}+\mathrm{pAAM}$ & $\mathrm{P}_{\mathrm{ars}}+\mathrm{P}_{\mathrm{BAD}}$ & $\begin{array}{l}\text { NIR } \\
\text { fluorescence }\end{array}$ & Arsenite biosensor & 9 \\
\hline
\end{tabular}

For Escherichia coli strains, vectors are replicative plasmids; for Deinococcus deserti, vectors are inserted within the amylase gene by homologous recombination. The pRpoD-lux and pArslux vectors have been described elsewhere (Prévéral et al. 2016)

Culture conditions for E. coli and D. deserti

When required, antibiotics were added in the culture media. For E. coli, kanamycin, ampicillin, and tetracycline were used at 50,50, and $10 \mu \mathrm{g} / \mathrm{ml}$, respectively. For $D$. deserti, kanamycin was used at $10 \mu \mathrm{g} / \mathrm{ml}$. E. coli strains were aerobically cultivated in Lysogeny Broth (LB) medium at $37{ }^{\circ} \mathrm{C}$ in agitated Erlenmeyer flasks $(150 \mathrm{rpm})$. When required, $1 \% \mathrm{~L}$-arabinose was added to induce the expression of the genes driven by the $\mathrm{P}_{\mathrm{BAD}}$ promoter. D. deserti strains were 
aerobically cultivated in ten-fold diluted Tryptic Soy Broth (TSB) at $30{ }^{\circ} \mathrm{C}$ in agitated Erlenmeyer flasks $(150 \mathrm{rpm})$.

\section{Lyophilization of $E$. coli cells}

E. coli cells were grown aerobically in LB medium at $37{ }^{\circ} \mathrm{C}$ under agitation $(150 \mathrm{rpm})$ until early exponential phase $\left(\mathrm{OD}_{600 \mathrm{~nm}}=0.2-0.3\right)$. The cultures were then centrifuged and cells resuspended in $\mathrm{LB}+12 \%$ sucrose to an $\mathrm{OD}_{600 \mathrm{~nm}}$ equal to 0.5. Aliquots of $500 \mu \mathrm{l}$ in $2 \mathrm{ml}$ Eppendorf tubes of these bacterial cultures were frozen at $-80{ }^{\circ} \mathrm{C}$ and then lyophilized for $24 \mathrm{~h}$ in a Christ Alpha 12 LD Freeze Dryer. The lyophilized aliquots were stored under nitrogen atmosphere at $4{ }^{\circ} \mathrm{C}$ until use.

Bioluminescence, NIR fluorescence, and absorbance measurements

Single-point absorbance measurements at $600 \mathrm{~nm}\left(\mathrm{OD}_{600 \mathrm{~nm}}\right)$ were done with a Cary® $50 \mathrm{UV}$ visible spectrophotometer from Agilent Technologies. Single-point bioluminescence emission measurements described in Fig. 1a were performed on a GloMax ${ }^{\circledR}$ 20/20 luminometer from Promega. For this, E. coli cultures were inoculated at $\mathrm{OD}_{600 \mathrm{~nm}}=0.01-0.03$ and cultivated until the exponential phase $\left(\mathrm{OD}_{600 \mathrm{~nm}}=0.3\right.$ for $\mathrm{pRpoD}$-lux cell-survival biosensor and $\mathrm{OD}_{600 \mathrm{~nm}}=0.2$ for pArs-lux arsenite biosensor). We measured the bioluminescence emission after 45 min of incubation at $30{ }^{\circ} \mathrm{C}$ in 2-ml Eppendorf tubes containing $500 \mu \mathrm{l}$ of E. coli culture, contaminated with $2.7 \mu \mathrm{M}$ arsenite for pArs-lux biosensor. In general, with the multi-mode micro-plate reader Infinite ${ }^{\circledR} 200$ Pro from TECAN, the kinetics were measured at $30{ }^{\circ} \mathrm{C}$ under regular shaking in sterilized Greiner 96-well black plate and clear bottom, with the apparatus set at $450 \mathrm{~nm}$ for bioluminescence, excitation at $685 \mathrm{~nm}$, and emission at $755 \mathrm{~nm}$ for NIR fluorescence and $600 \mathrm{~nm}$ for absorbance. In these different experiments, for both $E$. coli and D. deserti, each well in the micro-plate contained $100 \mu \mathrm{l}$ of cell culture suspension and $100 \mu \mathrm{l}$ of a solution containing the additives when required (antibiotics, L-arabinose, sodium arsenite, or kaolin). As the preparation details for the $100-\mu 1$ cell suspension depended on the strain and the type of experiment performed, they are summarized in Table $\underline{4}$.
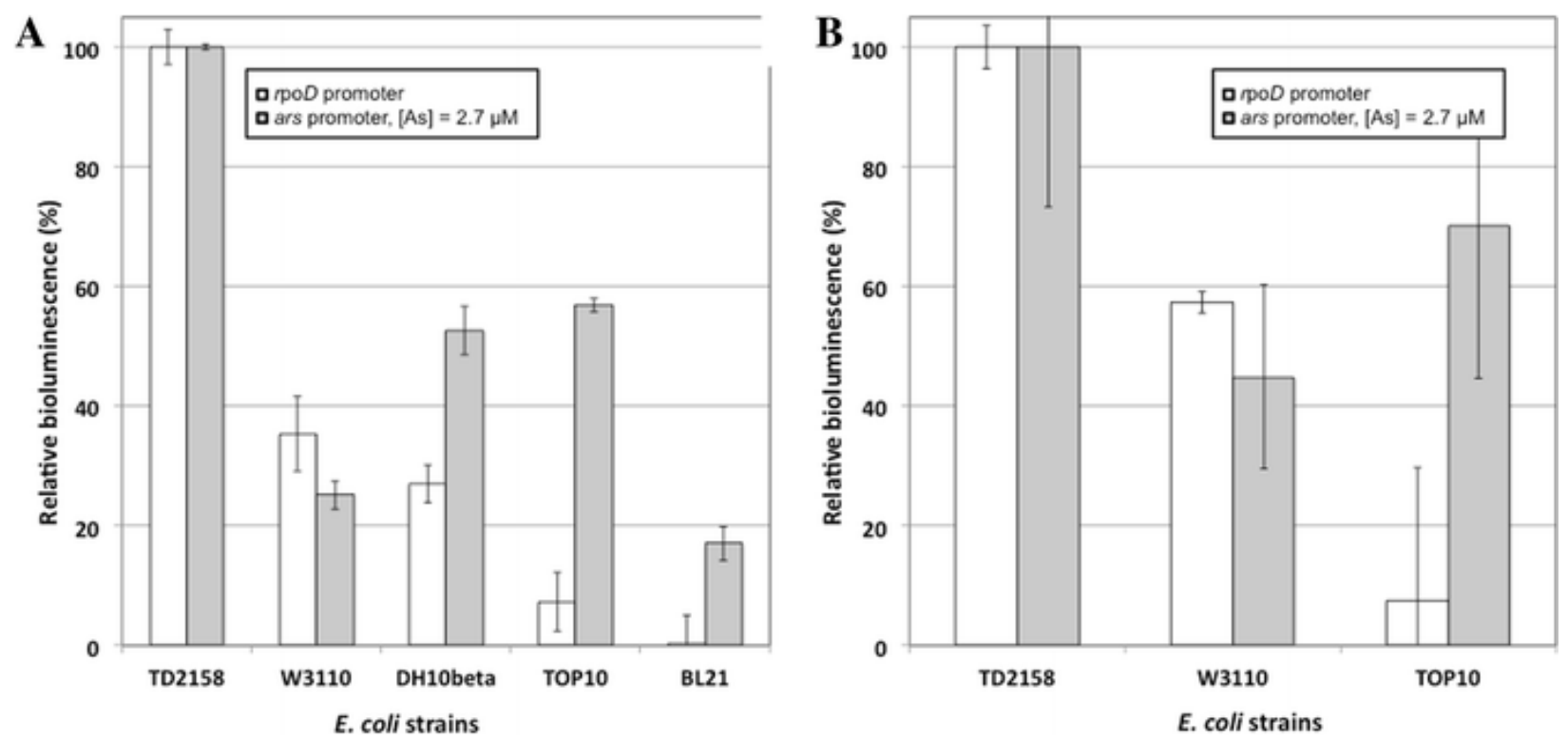

Fig. 1

Impact of the Escherichia coli host strain on the biosensor relative bioluminescence emission. a Measurements made on growing cells after 45 min incubation. $2.7 \mu M$ arsenite was added to the pArs biosensor at $t=0 \mathrm{mn} . \boldsymbol{b}$ Measurements made on revived lyophilized cells after $60 \mathrm{~min}$ incubation. $2.7 \mu \mathrm{M}$ arsenite was added to the pArs biosensor at $t=0 \mathrm{mn}$. For a given biosensor, the signal is set at $100 \%$ for the strain exhibiting the maximum bioluminescence emission level. rpoD (white square) is the cell-survival biosensor and ars (gray square) is the arsenite biosensor. The E. coli strains used here are the wild-type strain TD2158 and the engineered strains W3110, Dh10beta, TOP10, and BL21. Measurements were done in triplicates (standard errors shown in panels $\boldsymbol{a}$ and $\boldsymbol{b}$ ) 


\section{Table 4}

Cell suspension preparation for E. coli and D. deserti prior to absorbance, bioluminescence, and NIR-fluorescence kinetics with the multi-mode micro-plate reader Infinite ${ }^{\circledR} 200$ Pro from TECAN

\begin{tabular}{l|l|l} 
Strain & Figure & Cell preparation for 96-wells micro-plates
\end{tabular}

\begin{tabular}{|c|c|c|}
\hline $\begin{array}{l}\text { Escherichia } \\
\text { coli }\end{array}$ & $1 \mathrm{~B}$ & $\begin{array}{l}\text { Lyophilized aliquot resuspended in } 500 \mu \mathrm{l} \text { of } \\
\text { water and incubated } 20 \mathrm{~min} \text { at } 30^{\circ} \mathrm{C}\end{array}$ \\
\hline $\begin{array}{l}\text { Deinococcus } \\
\text { deserti }\end{array}$ & 2,3 & Inoculated from overnight culture. \\
\hline $\begin{array}{l}\text { Deinococcus } \\
\text { deserti }\end{array}$ & $5 \mathrm{~A}$ & $\begin{array}{l}\text { Overnight culture inoculated at } \\
\text { OD }_{600 \mathrm{~nm}}=0.01, \text { harvested in exponential } \\
\text { phase at } \mathrm{OD}_{600 \mathrm{~nm}} \approx 0.1 \text { and resuspended at } \\
\mathrm{OD}_{600 \mathrm{~nm}}=1.2\end{array}$ \\
\hline $\begin{array}{l}\text { Deinococcus } \\
\text { deserti }\end{array}$ & $\begin{array}{l}5 \mathrm{~B} \\
5 \mathrm{C}\end{array}$ & $\begin{array}{l}\text { Air-dried cells resuspended in } \mathrm{TSB} / 10 \text { at } \\
\mathrm{OD}_{600 \mathrm{~nm}}=1.2\end{array}$ \\
\hline $\begin{array}{l}\text { Escherichia } \\
\text { coli }\end{array}$ & $7-9$ & $\begin{array}{l}\text { Inoculation at } \mathrm{OD}_{600 \mathrm{~nm}}=0.01-0.03, \text { harvested } \\
\text { in early exponential phase at } \mathrm{OD}_{600 \mathrm{~nm}} \approx 0.25 \\
\text { and resuspensed at } \mathrm{OD}_{600 \mathrm{~nm}}=1.2\end{array}$ \\
\hline
\end{tabular}

Overnight cultures are always prepared prior to the experiments in the prescribed media with the required additives when needed (antibiotics, L-arabinose), serving as inoculum

\section{Bioinformatics}

For genomic analysis, the genome sequence of M. magneticum AMB-1 (Matsunaga et al. 2005) was imported into the microbial genome expert annotation system MaGe (Vallenet et al. 2006) provided by the Génoscope (https://www.genoscope.cns.fr). We identified a previously undetected gene, which we named magBphP, encoding a putative bacteriophytochrome. The gene sequence was deposited in Genbank (no. BK009263) as a third party annotation.

\section{Bacteriophytochrome expression and purification}

Giraud et al. designed the РРФ3295 plasmid for heterologous expression in E. coli of functional bacteriophytochromes from Rhodopseudomonas palustris (Giraud and Verméglio 2008). Briefly, the apo-bacteriophytochrome gene is cloned between the BgIII and EcoRI restrictions sites, resulting in addition of a 6-histidine tag at the N-terminus of the protein; it is followed by the $h m u O$ gene from Bradyrhizobium sp. ORS 278 that encodes the heme oxygenase required to oxidize a heme into biliverdin. The expression of both genes is driven by the L-arabinose inducible promoter araBAD ( $\mathrm{P}_{\mathrm{BAD}}$ ) (Guzman et al. 1995). We amplified the magBphP gene by high-fidelity PCR from M. magneticum AMB-1 genomic DNA (primer nos. 1 and 2); this PCR fragment was then digested with BgIII and EcoRI restriction enzymes and cloned into the PPФ3295 after digestion by the same restriction enzymes and excision of the $R$. palustrisbacteriophytochrome gene, yielding the pMagBphP plasmid. The latter was then introduced into $E$. coli Dh10beta. For protein expression, two 3-L Erlenmeyer flasks containing $500 \mathrm{ml}$ of Terrific Broth medium (Life technologies) were inoculated (1/100) with an overnight pre-culture of $E$. coli transformed with pMagBphP plasmid. Cells were grown at $37{ }^{\circ} \mathrm{C}, 150 \mathrm{rpm}$ agitation, until $\mathrm{OD}_{600 \mathrm{~nm}} 0.6$ was reached. Protein expression was then induced by the addition of $0.1 \%(w / v)$ of L-arabinose (Sigma-Aldrich), bacterial growth taking place now at $25^{\circ} \mathrm{C}$ overnight. Cells of emerald green color were harvested $\left(7500 \mathrm{~g}, 10 \mathrm{~min}, 4^{\circ} \mathrm{C}\right)$, washed twice in 
buffer A (20 mM phosphate buffer, $500 \mathrm{mM} \mathrm{NaCl}, \mathrm{pH}$ 8), and finally resuspended in $30 \mathrm{ml}$ of the same buffer. DNase I and protease inhibitor cocktail (Sigma-Aldrich) were added prior to cell disruption by French Press (three times, 1000 psi, $4{ }^{\circ} \mathrm{C}$ ). Unbroken cells and debris were removed by centrifugation $\left(7500 \mathrm{~g}, 10 \mathrm{~min}, 4^{\circ} \mathrm{C}\right)$. Ultracentrifugation of the supernatant $(45,000 \mathrm{~g}, 90 \mathrm{~min}$, $4{ }^{\circ} \mathrm{C}$ ) yielded $24 \mathrm{ml}$ of a dark emerald green soluble fraction. After filtration on a $0.22-\mu \mathrm{m}$ disposable filtration unit, this supernatant was loaded $\left(1 \mathrm{ml} \mathrm{min}^{-1}\right)$ onto a 5-ml HisTrap Nickel affinity column (Amersham) equilibrated with buffer A. The column was washed with $50 \mathrm{ml}$ of buffer $\mathrm{A}$, then $50 \mathrm{ml}$ of buffer $\mathrm{A}+50 \mathrm{mM}$ imidazole. The bound protein was eluted by $25 \mathrm{ml}$ of buffer A $+125 \mathrm{mM}$ imidazole and concentrated to a final volume of $2.5 \mathrm{ml}$ on a Centricon NW30 unit (Millipore). The entire protein sample was then loaded onto a desalting PD-10 column (Life Technologies) equilibrated with Buffer B (20 mM HEPES, pH 8) then eluted with $3.5 \mathrm{ml}$ of the same buffer.

\section{Construction of bioluminescent biosensors in $D$. deserti}

The genetic modification of $D$. deserti was obtained by chromosomal insertion of constructed cassettes. For the insertion location on the bacterial chromosome, we selected the amylaseencoding amyE gene (gene ID Deide_08810), which is not essential for growth of D. deserti. We designed three bioluminescent strains where the luxCDABE operon encoding the bacterial luciferase from Photorhabdus luminescens (Winson et al. 1998) is controlled by a $D$. deserticonstitutive promoter $\mathrm{P}_{\text {gapdh }}$ (from gene Deide_11420 encoding glyceraldehyde-3phosphate dehydrogenase) (plasmid pAGLT), by an E. coli arsenite-inducible promoter $\mathrm{P}_{\text {ars }}$ (plasmid pAALT) or is left promoter-less (plasmid pALT). The pUC18 plasmid, not replicative in $D$. deserti, was used as a backbone (Dulermo et al. 2009). We first amplified by high-fidelity PCR the amyE sequence from $D$. deserti genomic DNA (primer nos. 3 and 4 ) and cloned it into pUC18 (Norrander et al. 1983) between HincII and SacI restriction sites, yielding the pUC18-amyEDD plasmid. We obtained the luxCDABE operon by enzymatic restriction (SnabI and BamHI) from the plasmid pArs-lux and cloned it into a pBluescript II SK(+) from Agilent Technologies (pBSKII) at the corresponding sites, yielding the pBSK-lux plasmid. The Ptuf::kan fragment, comprising the kanamycin resistance gene under the control of the $D$. deserti $\mathrm{P}_{\text {tuf }}$ promoter (Dulermo et al. 2009), was obtained by enzymatic restriction (BamHI and $\mathrm{XbaI})$ of pSF0kan and cloned at the corresponding sites in pBSK, yielding the pBSK-luxPtuf::kan plasmid. We then amplified the entire pUC18-AmyEDD with a primer pair (primer nos. 5 and 6) introducing ApaI and XbaI restriction sites in the middle of the amyE sequence. After enzymatic restriction by ApaI and XbaI, this PCR product was ligated to the luxCDABE + Ptuf::kan cassette obtained by enzymatic restriction (ApaI and XbaI) of pBSKlux-Ptuf::kan, yielding the pALT plasmid (promoter-less expression of lux). Insertions of $\mathrm{P}_{\text {gapdh }}$ and $\mathrm{P}_{\text {arspromoters }}$ were realized by the In-Fusion ${ }^{\circledR} \mathrm{HD}$ cloning technique (Clontech) in pALT digested with ApaI and SnabI restriction enzymes, yielding pAGLT and pAALT plasmids, respectively. $\mathrm{P}_{\text {gapdh }}$ and $\mathrm{P}_{\text {ars }}$ promoters were obtained by PCR from $D$. deserti genomic DNA (primer nos. 7 and 8) and pArs-lux plasmid (primer nos. 9 and 10), respectively. The insertion of the various lux cassettes in $D$. deserti's genome was obtained via double homologous recombination in $D$. deserti genome at the amyE locus after transformation of the cells with pALT, pAGLT, or pAALT. Transformation of chemically competent cells was performed as described (Dulermo et al. 2009). The double homologous recombination at the correct locus and insertion of the cassette of interest were systematically confirmed by diagnostic PCR.

\section{Cell survival after desiccation of E. coli and D. deserti containing the arsenite $\mathrm{P}_{\text {ars }}$ biosensor}

We transferred the corresponding arsenite biosensors into E. coli TD2158 and D. deserti RD19. For desiccation, exponential $\left(\mathrm{OD}_{600 \mathrm{~nm}}=0.1\right.$ for $D$. deserti and 0.6 for $E$. coli) phase cells were concentrated to an $\mathrm{OD}_{600 \mathrm{~nm}}=20$ and placed on sterile glass slides $(100 \mu \mathrm{l}$ cells per slide), dried and stored at room temperature in a sealed desiccator over anhydrous $\mathrm{CaSO}_{4}$. The $\mathrm{CaSO}_{4}$ desiccant is impregnated with $\mathrm{CoCl}_{2}$. This latter chemical compound is a visual moisture indicator: anhydrous $\mathrm{CoCl}_{2}$ is blue while pink in the presence of water. After storage at room temperature for 1 and 7 days, cells were resuspended in TSB/10 (D. deserti) or LB (E. coli), 
serially diluted, and plated. After growth, colonies were counted to determine survival compared to non-desiccated cells.

Construction of a near-infrared fluorescent biosensor in E. coli

The NIR fluorescent biosensor relies on two plasmids co-introduced into $E$. coli. The pAAM plasmid comprises the $M$. magneticum AMB-1 bacteriophytochrome structural gene magBphPwhose expression is driven by the L-arabinose-inducible $\mathrm{P}_{\mathrm{BAD}}$ promoter. The pBAH plasmid includes the heme oxygenase gene $h m u O$ from Bradyrhizobium sp. ORS 278 under the control of the arsenite-inducible $\mathrm{P}_{\text {ars }}$ promoter from E. coli. Plasmid pAAM was constructed by cloning the fragment containing the regulatory gene $\operatorname{araC}$, the $\mathrm{P}_{\mathrm{BAD}}$ promoter and magBphP, obtained from pMagBphP by high-fidelity PCR (primer nos. 11 and 12), into pACYC184 plasmid (Rose 1988) at the EcoRI restriction site by In-Fusion ${ }^{\circledR}$ HD cloning technique (Clontech). An intermediary plasmid pBMH was constructed by In-Fusion ${ }^{\circledR}$ HD cloning technique. The enzymatic restriction of plasmid pBSKII(+) by BssHII produced Fragment no. 1; the sequence containing the mercury-inducible $\mathrm{P}_{\text {mer }}$ promoter was obtained by high-fidelity PCR (primer nos. 13 and 14) from pMer-lux plasmid, yielding Fragment no. 2; and the $h m u O$ gene sequence was obtained by high-fidelity PCR (primer nos. 15 and 16) from pMagBphP, yielding Fragment no. 3. The ordered assembly of Fragment nos. 1, 2, and 3 was realized according to the manufacturer protocol. The pBMH plasmid was then digested with NcoI and ApaI restriction enzymes to remove the $\mathrm{P}_{\text {mer }}$ promoter, yielding Fragment no. 4; the sequence containing the arsenite-inducible $\mathrm{P}_{\text {ars }}$ promoter was obtained by high-fidelity PCR from pArs-lux and ligated to Fragment no. 4 with the In-Fusion ${ }^{\circledR}$ HD cloning technique, yielding plasmid pBAH. After verification by DNA sequencing, plasmids pAAM and pBAH were co-introduced into E. coliDh10beta chemically competent cells.

\section{Nephelometry}

A kaolin stock solution at 4000 Nephelometric turbidity units (NTU) was prepared by dissolving $400 \mathrm{mg}$ of kaolin into $100 \mathrm{ml}$ of water. Serial dilutions were made in water to obtain a range of 0-500 NTU. For bioluminescence and NIR fluorescence assays, we used the cell-survival pRpoD-lux biosensor in E. coli TD2158 and pMagBphP in E. coli Dh10beta, respectively. Absorbance, bioluminescence, and NIR fluorescence kinetics were then recorded as described above.

\section{Results}

Influence of the host strain for a bioluminescent bacterial biosensor

\section{Are there optimal $E$. coli strains to harbor bacterial biosensors?}

Each academic laboratory involved in project COMBITOX used its own selection of $E$. colistrains to host its biosensors and it became fairly evident that the genetic background had an impact on the bioluminescence emission. In order to validate general rules relevant for the construction and optimization of new whole-cell detectors within the COMBITOX framework, we measured the bioluminescence emission in 5 different $E$. coli strains (TD2158, W3110, DH10beta, TOP10 and BL21) harboring 2 different lux-based biosensors. In the cell-survival pRpoD-lux biosensor, the lux operon is transcriptionally fused to the constitutive $\mathrm{P}_{\mathrm{rpoD}}$ promoter, whereas pArs-lux is a metal biosensor where the lux operon is transcriptionally fused to the $\mathrm{P}_{\text {ars }}$ (arsenite-inducible) promoter. Both pRpoD-lux and pArs-lux biosensors have been fully characterized and are published in this special issue (Prévéral et al. 2016).

In Fig. $\underline{1 a}$, we summarized the relative bioluminescence levels that were measured with growing E. coli cells. Depending on the $E$. coli host strain, we observed important variations of the bioluminescence emission levels for each biosensor that was tested $45 \mathrm{~min}$ after the beginning of the experiment. At this time, the bioluminescence emission is maximum for all strains tested and the emission kinetics are similar, with no lag phase recorded (data not shown). Variations are 
the most important for the cell-survival pRpoD-lux biosensor, with the maximal signal obtained in TD2158 (100\%), only $7 \%$ remaining in TOP10 and almost nothing measured in BL21. For the arsenite biosensor, there is more than a five-fold decrease of light emission when transferred from TD2158 to BL21. To summarize, the wild-type E. coli TD2158 strain would be a reasonable compromise in living cells with optimum bioluminescence emission measured for both the cell survival and the arsenite biosensor; nevertheless, we observed in another context on fresh cells for a cadmium biosensor designed on the same scaffold as $\mathrm{P}_{\mathrm{rpoD}}$ and $\mathrm{P}_{\text {ars }}$ that TD2158 comes in a second position after TOP10 (unpublished data). Lyophilized cells when revived and eventually challenged with arsenite do follow the same trend as the non-lyophilized cultures (Fig. $\underline{1 b}$ ), although with a 15-min delay when compared to the fresh cells (Fig. $\underline{1 \mathrm{a}}$ ). Indeed, the emission kinetics are similar for all strains but this time with an initial lag phase resulting in a maximum bioluminescence emission observed $60 \mathrm{~min}$ after the beginning of the experiment (data not shown). These kinetics indicate that the global effect of the lyophilization procedure on E. coli is similar regardless the strain or the biosensor. All together, these observations suggest that there is not a universal, optimal host strain within the same species, each bioluminescent biosensor requiring a separate optimization.

\section{Is an environmental desiccation-resistant strain (D. deserti) more adapted to harbor biosensors?}

We further investigated the influence of the cellular chassis by constructing a cell survival and an arsenite biosensor in $D$. deserti, a bacterium isolated from a desert environment (de Groot et al. 2005) exhibiting a high resistance to DNA-damaging stresses such as UV and gamma irradiation as well as desiccation. This bacterial strain is thus likely to be more resistant than are laboratory E. coli strains to on-field measurements on environmental samples. Keeping in mind the economical constraints on the production of biosensors as reagents for water analyzer, $D$. deserti would also be a good candidate to host biosensors with desiccation as a simple, costeffective conservation process.

We intend here to demonstrate the feasibility of a bioluminescent arsenite sensor hosted in $D$. deserti derived from the pArs-lux biosensor previously hosted in E. coli. To start with, this proofof-concept requires evaluating the ability of $D$. deserti to express a functional, bioluminescent bacterial luciferase. To address this, we inserted the transcriptional fusion between the $D$. deserti gapdh promoter $\left(\mathrm{P}_{\text {gapdh }}\right)$ and the luxCDABE operon into the amylase gene $(a m y E)$, which is not essential for aerobic growth of $D$. deserti (Fig. 2). The gapdh gene is among the most highly expressed genes in $D$. desertion the basis of RNAseq data (de Groot et al. 2014). The bioluminescence emission kinetics shown in Fig. $\underline{2}$ demonstrate the ability of $D$. deserti to produce both the bacterial luciferase and its substrate under the supervision of the $\mathrm{P}_{\text {gapdh }}$ promoter, although the time course of bioluminescence emission is slow. Little background bioluminescence was observed in the absence of any promoter fused to the luxoperon. 


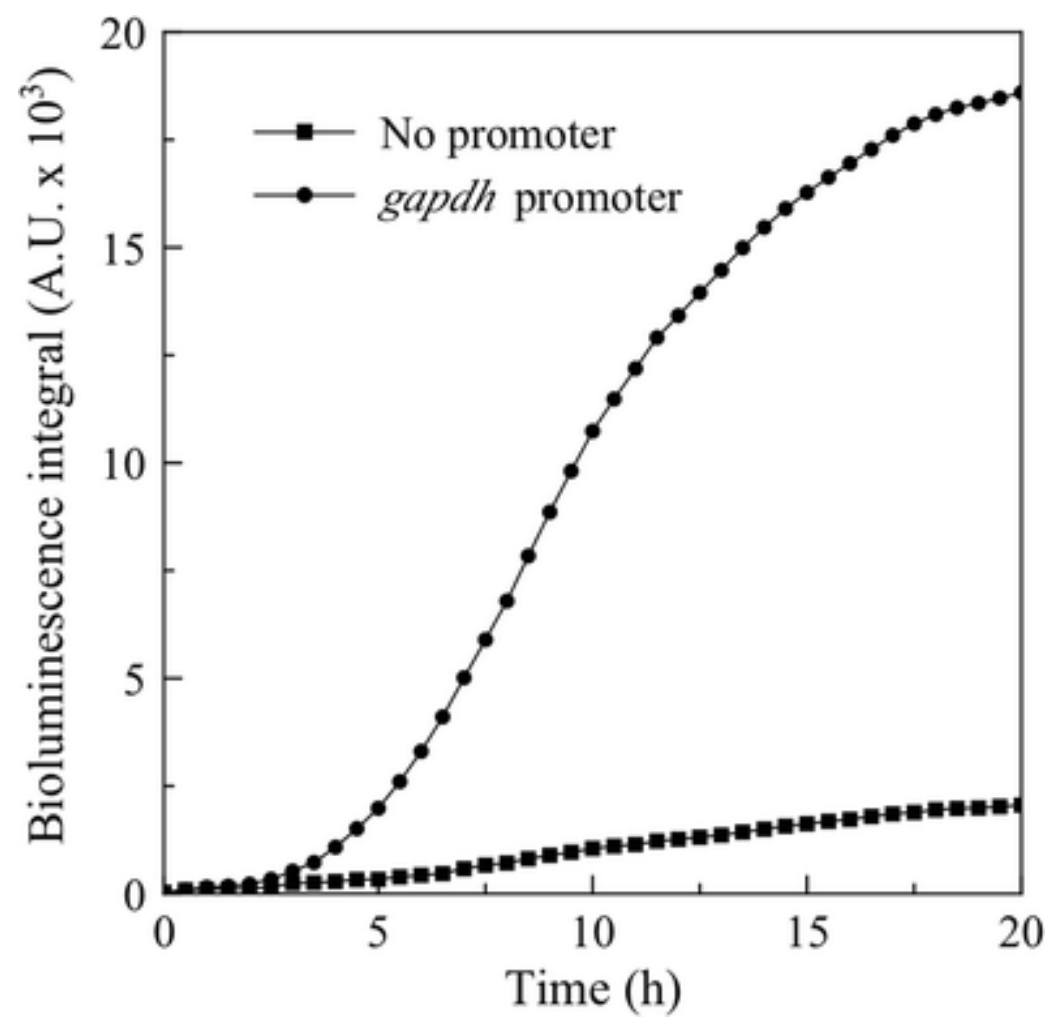

Fig. 2

Bioluminescence emission kinetics in Deinococcus deserti. Chromosomal insertion within the amyE gene of the lux operon without promoter (black square) or under the control of $P_{\text {gapdh }}$ promoter (black circle)

We then replaced $\mathrm{P}_{\text {gapdh }}$ by the arsenite-inducible $\mathrm{P}_{\text {ars }}$ promoter in the chromosomal insertion and measured the bioluminescence emission after arsenite addition (Fig. $\underline{3}$ ). This genetic modification led to a functional biosensor that emits light in a dose-response manner to arsenite, although the $\mathrm{P}_{\text {ars }}$ promoter originates from a distantly related bacterium. As observed with pArs-lux in $E$. coli (Prévéral et al. 2016), the baseline bioluminescence is significantly high without arsenite added, most probably due to an incomplete binding of the ArsR repressor to the ars-promoting region. Nevertheless, a concentration as low as $100 \mathrm{nM}$ arsenite results in a significant increase of bioluminescence emission with respect to this baseline level (Fig. 3a). Saturation is reached between 5 and $10 \mu \mathrm{M}$, corresponding to a range of arsenite concentrations where $D$. deserti growth begins to be affected (not shown). The time response of this arsenite biosensor in $D$. deserti is slow as shown in Fig. $\underline{3 b}$ : it takes between 10 and $15 \mathrm{~h}$ to be sensitive enough to detect small variations of arsenite concentrations. This is 10 to 20 times slower than in $E$. coli where reliable measurements can be obtained between 30 and $60 \mathrm{~min}$ after contamination. As a conclusion, the time response in $D$. deserti is slow whatever the promoter $\left(\mathrm{P}_{\text {gapdh }}\right.$ or $\left.\mathrm{P}_{\text {ars }}\right)$ and this may be related to the slower cell cycle of $D$. deserti and a lower expression. 

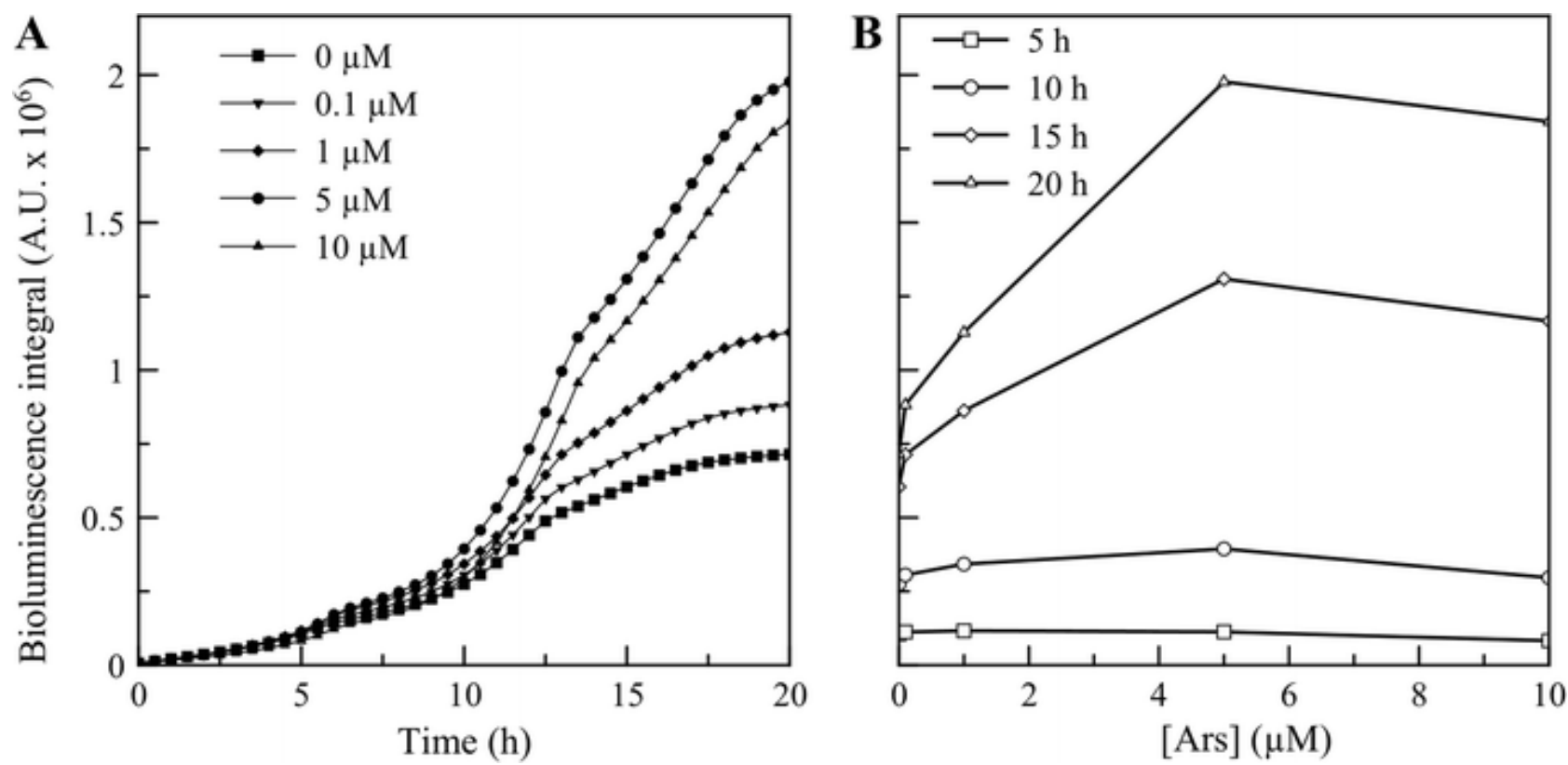

Fig. 3

Arsenite-induced bioluminescence emission in recombinant Deinococcus deserti. aIntegral of the bioluminescence emission over time for increasing concentrations of arsenite. $\boldsymbol{b}$ Bioluminescence dose response at different sampling times $(5,10,15$, and $20 \mathrm{~h})$ after addition of arsenite $(0,0.1$, $1,5$, and $10 \mu \mathrm{M})$. Initial $O D_{600 n m}$ is equal to 0.1 and arsenite is added at $t=0 \mathrm{~h}$

We completed the proof-of-concept of a $D$. deserti-based arsenite biosensor by investigating the bioluminescence recovery and response to arsenite with air-dried $D$. deserti cells. Using a very simple, non-optimized desiccation procedure applied to the arsenite biosensor hosted both in $E$. coli and $D$. deserti, we showed that the cell survival rate was more than five orders of magnitude higher for D. deserti than for E. coli after 7 days of desiccation (Fig. 4 ). One has to note that the $4 \%$ cell survival rate observed for the genetically modified $D$. deserti strain after 7 days is significantly lower than for the WT strain $(50 \%)$ measured 40 days after desiccation in another laboratory (de Groot et al. 2009). We believe that the genetic modification and the use of antibiotics likely impacts the cell fitness, hence its resistance to desiccation, and justifies a separate study for optimization of the desiccation protocol. Moreover, we used in this study the simplest procedure to air-dry the cells and different parameters can be adjusted to improve the cell survival rate such as temperature, evaporation kinetics, protectants, or vacuum drying. Figure $\underline{5}$ depicts the bioluminescence emission kinetics recorded after addition of increasing concentrations of arsenite to fresh $D$. deserti cells (Fig. $\underline{5 a}$ ) and to cells revived 1 (Fig. $\underline{5 b}$ ) and 7 days (Fig. 5c) after desiccation. In all cases, the arsenite biosensor responds in a similar fashion to arsenite concentrations ranging from 0.1 to $5 \mu \mathrm{M}$ (Fig. $\underline{5 \mathrm{~d}}$ ). For E. coli, little or no bioluminescence could be reliably observed (data not shown). We thus observe that desiccation preserves the sensitivity and the dynamic range of the bioluminescence emission in desiccated $D$. deserti cells but also impacts the time response of the biosensor. Indeed, we measured similar bioluminescence emission levels with $5-\mu \mathrm{M}$ arsenite added for the fresh and desiccated cells but with a 5 and $7 \mathrm{~h}$ delay for the 1- and 7-day desiccated cells, respectively. As a conclusion, the proof-of-concept of a bioluminescent arsenite biosensor with $D$. deserti is sound, although liable to optimization (codon usage, insertion locus, desiccation procedure), and a desiccation-resistant strain such as $D$. deserti remains a promising candidate to host bioluminescent biosensors. 


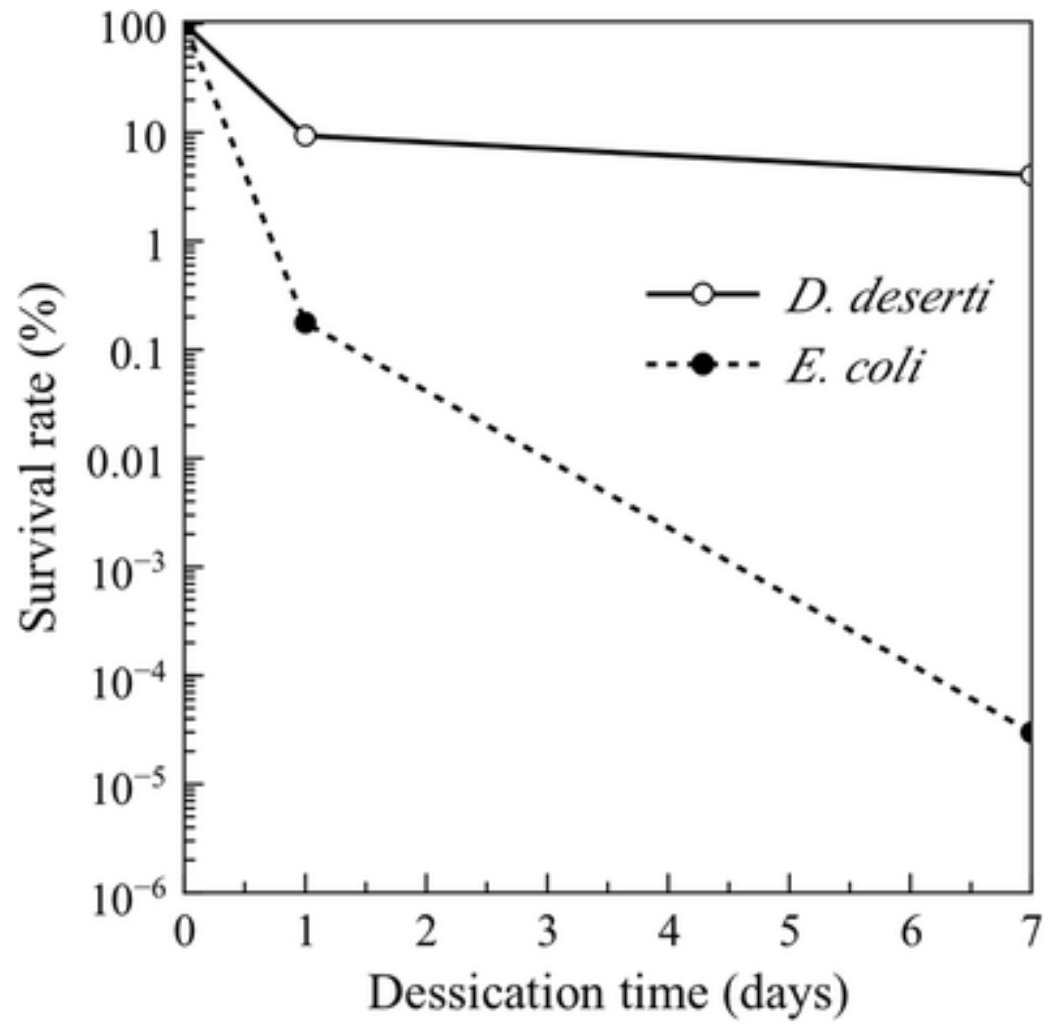

Fig. 4

Deinococcus deserti resistance to desiccation. Comparison of bacterial survival after desiccation for the arsenite biosensors hosted in D. deserti RD19 (white circle) and E. coli TD2158 (black circle). The $100 \%$ values correspond to $8.5 \times 10^{6}$ and $3.3 \times 10^{7}$ colony forming units for D. deserti and E. coli, respectively 

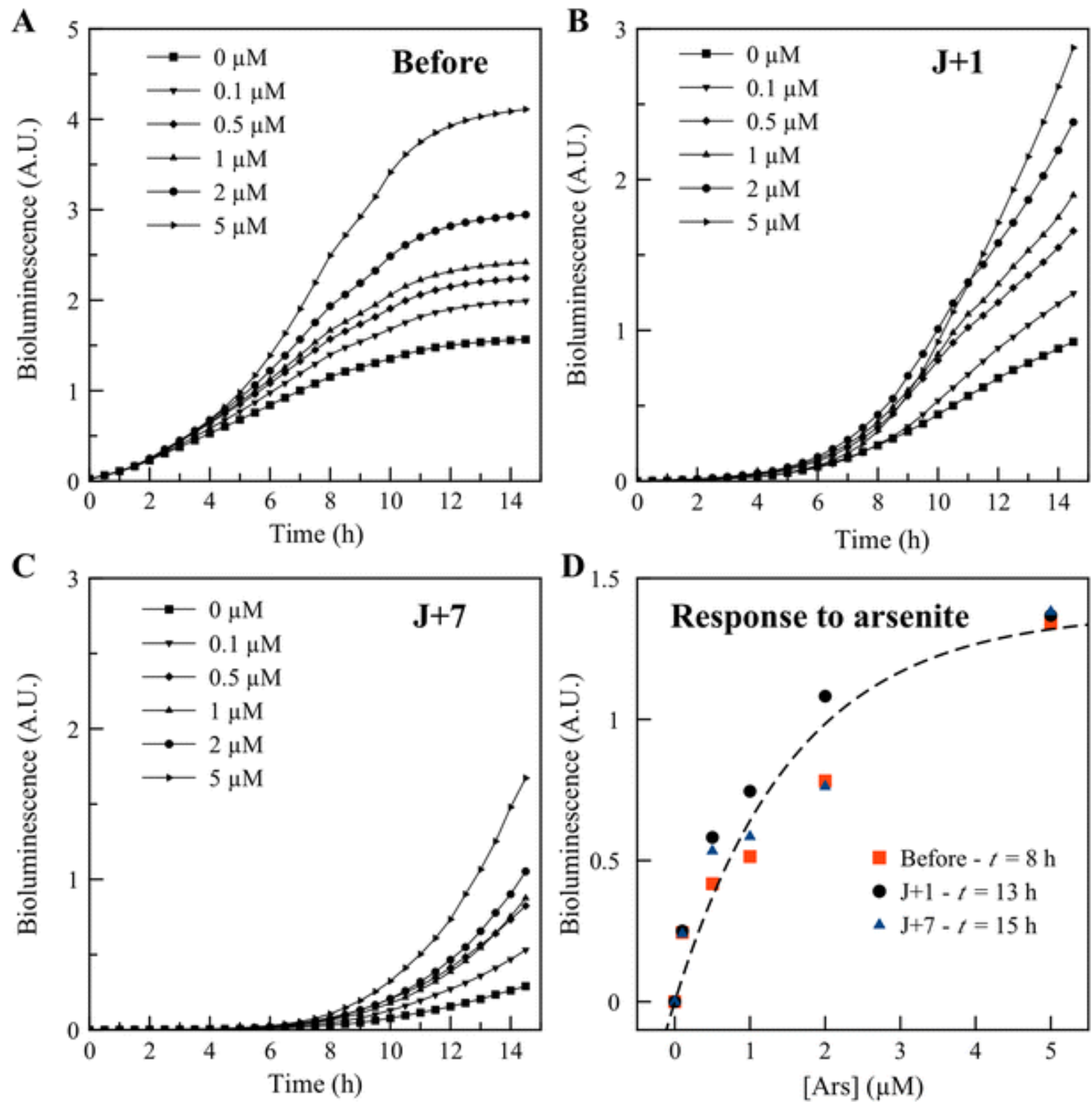

Fig. 5

Bioluminescence emission kinetics of D. deserti pArs biosensor upon addition of arsenite. Integration over time of the ratio (Bioluminescence emission/OD $600 \mathrm{~nm}$ ) for $\boldsymbol{a}$ fresh cells, $\boldsymbol{b}$ cells revived after 1 day of desiccation, and c cells revived after 7 days of desiccation. $\boldsymbol{d}$ Biosensor's response to arsenite for fresh (red square), 1-day desiccated (black circle), and 7-day desiccated (blue triangle) cells. In each case, we selected the sampling time where equivalent bioluminescence increases were observed with 5- $\mu M$ arsenite added with respect to the baseline, i.e. no addition of arsenite. The corresponding times are 8, 13, and $15 \mathrm{~h}$ for the fresh, 1-day desiccated, and 7-day desiccated cells, respectively

\section{Bacteriophytochromes as near-infrared fluorescent reporters for light biosensors}

As we previously evidenced, the whole-cell biosensor response is affected by the choice of the bacterial host and it is also strongly influenced by the selection of the reporter gene. This is notably true in the context of using biosensors under real life conditions, where environmental samples can be much more complex than in laboratory experiments; for instance turbidity and absorbing materials can drastically affect the emission and collection of bioluminescence emitted in lux-based whole-cell biosensors. In an attempt to propose an alternative to luciferase in such conditions, we turned to the characterization and the use of a near-infrared fluorescent reporter, the bacteriophytochrome MagBphP we identified while re-annotating the genome of the magnetotactic bacterium Magnetospirillum magnetic AMB-1. At variance with most bacteriophytochromes identified to date, MagBphP is naturally restricted to the chromophore- 
binding domain, with no transducing domain fused at the C-terminus as customary (Giraud and Verméglio 2008; Sharrock 2008). For the record, the engineered bacteriophytochrome from Deinococcus radiodurans used as a reporter for in vivo imaging in rodents is truncated to the same size and functional domain as MagBphP (Shu et al. 2009).

\section{In vitro characterization of a near-infrared fluorescent bacteriophytochrome}

The recombinant histidine-tagged MagBphP protein was purified on Ni-NTA column (Fig. $\underline{6 a}$ ), yielding an emerald green-colored protein typical of biliverdin-binding NIR light sensors (Fig. 6b). The purified bacteriophytochrome is fluorescent in the NIR spectrum, with a peak excitation at $715 \mathrm{~nm}$ and a maximum emission at $725 \mathrm{~nm}($ Fig. $\underline{6 \mathrm{c}})$. These spectroscopic features suggest that MagBphP is well suited for NIR detection and a good candidate for bacterial biosensors based on the reporter gene system.
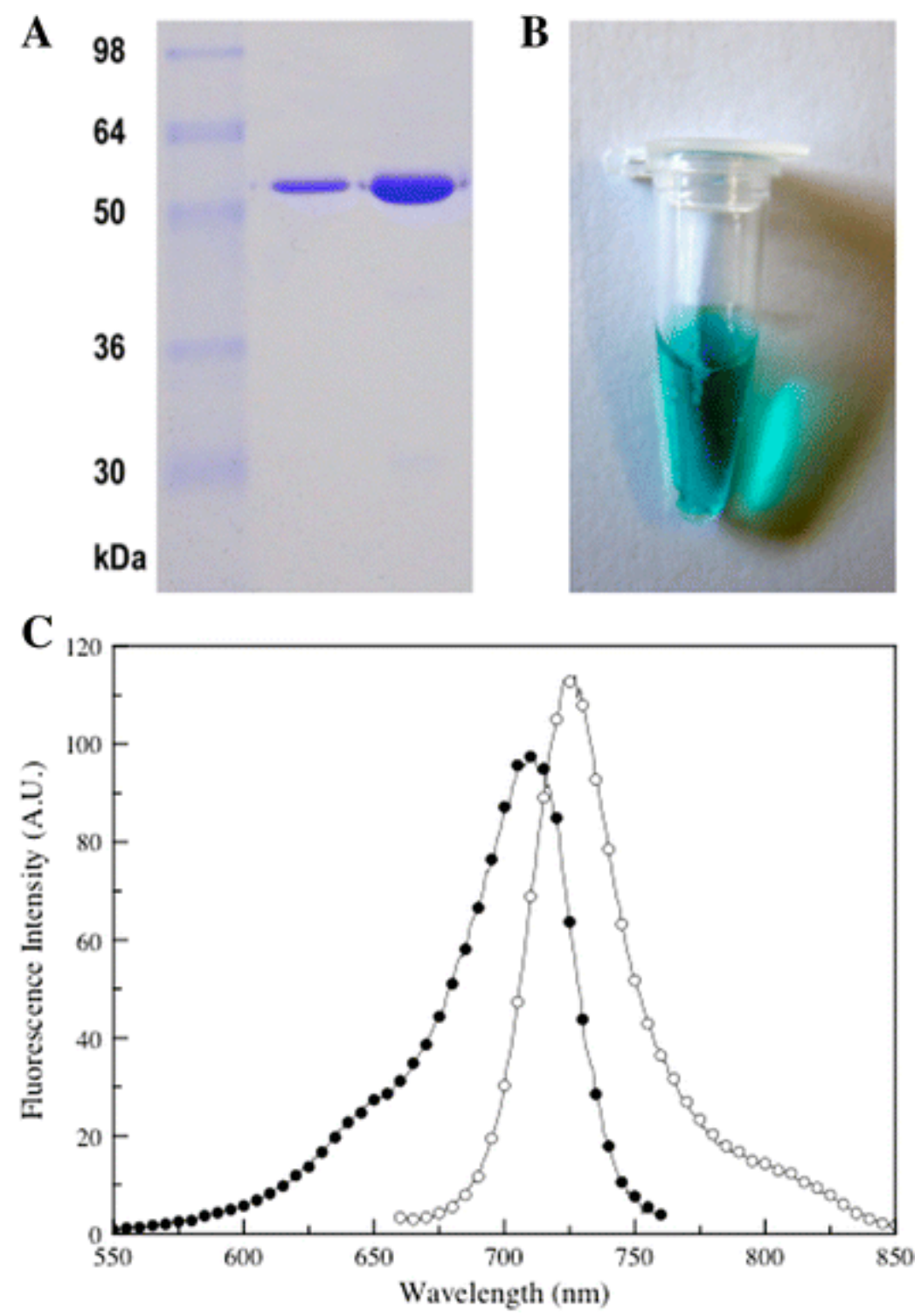

Fig. 6

MagBphP, a NIR fluorescent bacteriophytochrome from Magnetospirillum magneticum AMB1. a SDS-PAGE analysis of purified MagBphP after affinity chromatography (1 and $5 \mu \mathrm{g}$ of protein deposits, from left to right). MW markers are indicated on the left. $\boldsymbol{b}$ Photography of the purified protein displaying a typical emerald-green color due to the biliverdin moiety. c MagBphP excitation spectrum with fluorescence emission measured at $770 \mathrm{~nm}$ (black circle) and emission spectrum with fluorescence excitation set at $650 \mathrm{~nm}$ (white circle)

\section{Nephelometric measurements}

In the following study, we compared the evolution of the light signal with turbidity in two lightemitting E. coli strains, a bioluminescent cell survival biosensor (lux operon expression driven by the constitutive $\mathrm{P}_{\mathrm{rpoD}}$ promoter) and a near-infrared fluorescent cell survival biosensor 
(transcriptional fusion between the L-arabinose-inducible $\mathrm{P}_{\mathrm{BAD}}$ promoter controlling the expression of both the apo-bacteriophytochrome magBphP and heme oxygenase $h m u O$ genes). The turbidity of the bacterial LB growth medium was modified with the addition of a kaolin suspension to achieve a range of 0 to 500 nephelometric turbidity units (NTUs). Kaolin was preferred to formazine because we observed bacteriostatic effects of formazine on the growth of E. coli (data not shown). Cellular growth (Fig. 7a) and the fluorescence and bioluminescence kinetics (Fig. 7b) were recorded on a micro-plate reader. During the experiment, the bacteria were inoculated in the kaolin-modified LB medium (with $1 \% \mathrm{~L}$-arabinose when required) and incubated at $30^{\circ} \mathrm{C}$ under shaking. In these conditions, the microorganisms developed as shown in Fig. 7 a by the increase of the $\mathrm{OD}_{600 \mathrm{~nm}}$ without any significant effects of kaolin on the growth. We thus normalized the fluorescence and bioluminescence data with the $\mathrm{OD}_{600 \mathrm{~nm}}$ values to correct the variations due to biomass increase (Fig. $\underline{7 b}$ ). We then plotted the fluorescence or luminescence intensities against the turbidity at different times (Fig. $\underline{8}$ ), in the 60-120-min time range for the NIR fluorescence signal and 810-1020-min time range for the bioluminescence signal. In the latter case, the bioluminescence emission was significantly delayed. At each time point, data were normalized by the intensity measured at 0 NTU. For the bioluminescence signal, attenuation occurs very quickly when turbidity is increased (50\% loss at $75 \mathrm{NTU}$ ), while the signal remains optimal for NIR fluorescence in a large range of turbidity values (20\% loss at $500 \mathrm{NTU})$. We thus demonstrate here that the use of a bacteriophytochrome as a fluorescent reporter in the NIR spectrum represents a significant improvement to maintain the light signal fairly constant in a wide range of turbidity values.
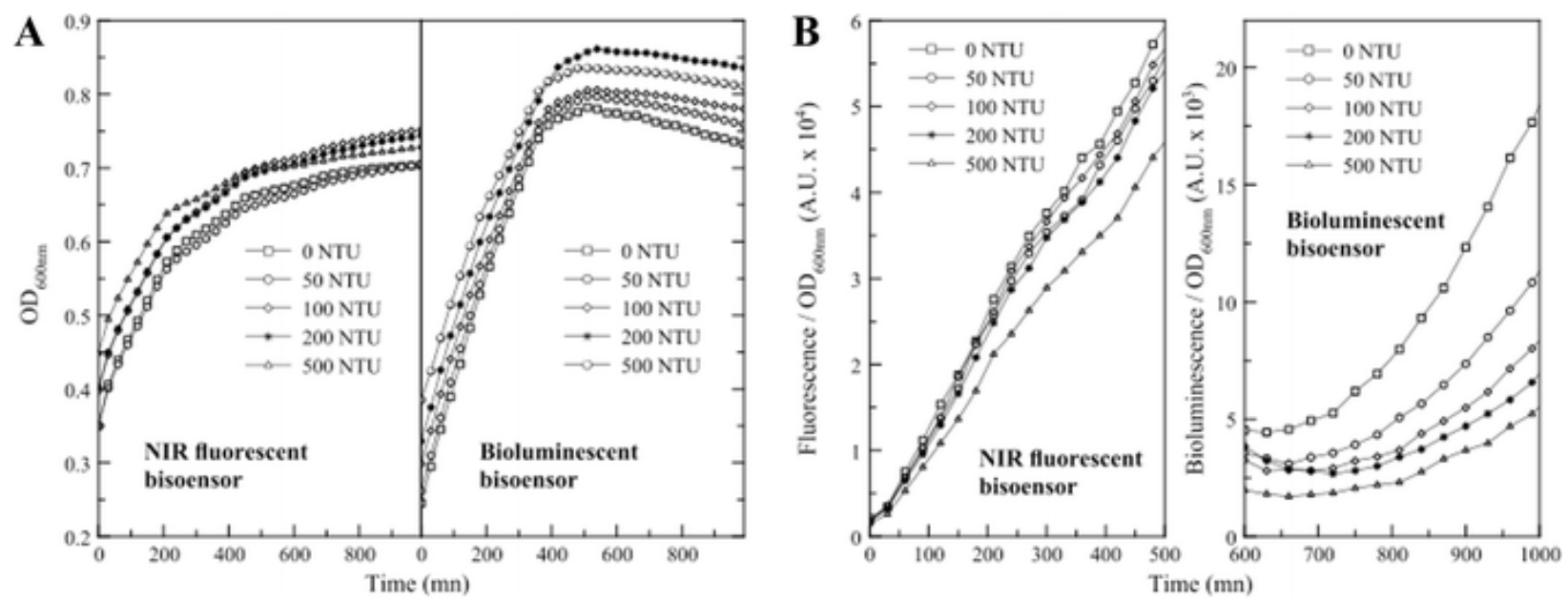

Fig. 7

Light emission and bacterial growth in turbid media. a OD kinetics measured at $600 \mathrm{~nm}$ for the NIR fluorescent (left panel) and the bioluminescent (right panel) biosensors at various turbidity values. $\boldsymbol{b}$ NIR fluorescence (left panel) and bioluminescence (right panel) emission kinetics for various turbidity values, normalized by the $O D_{600 n m}$. Fluorescence emission was measured at $755 \mathrm{~nm}$ with excitation set at $685 \mathrm{~nm}$. Turbidity was varied in the 0-500 NTU range 


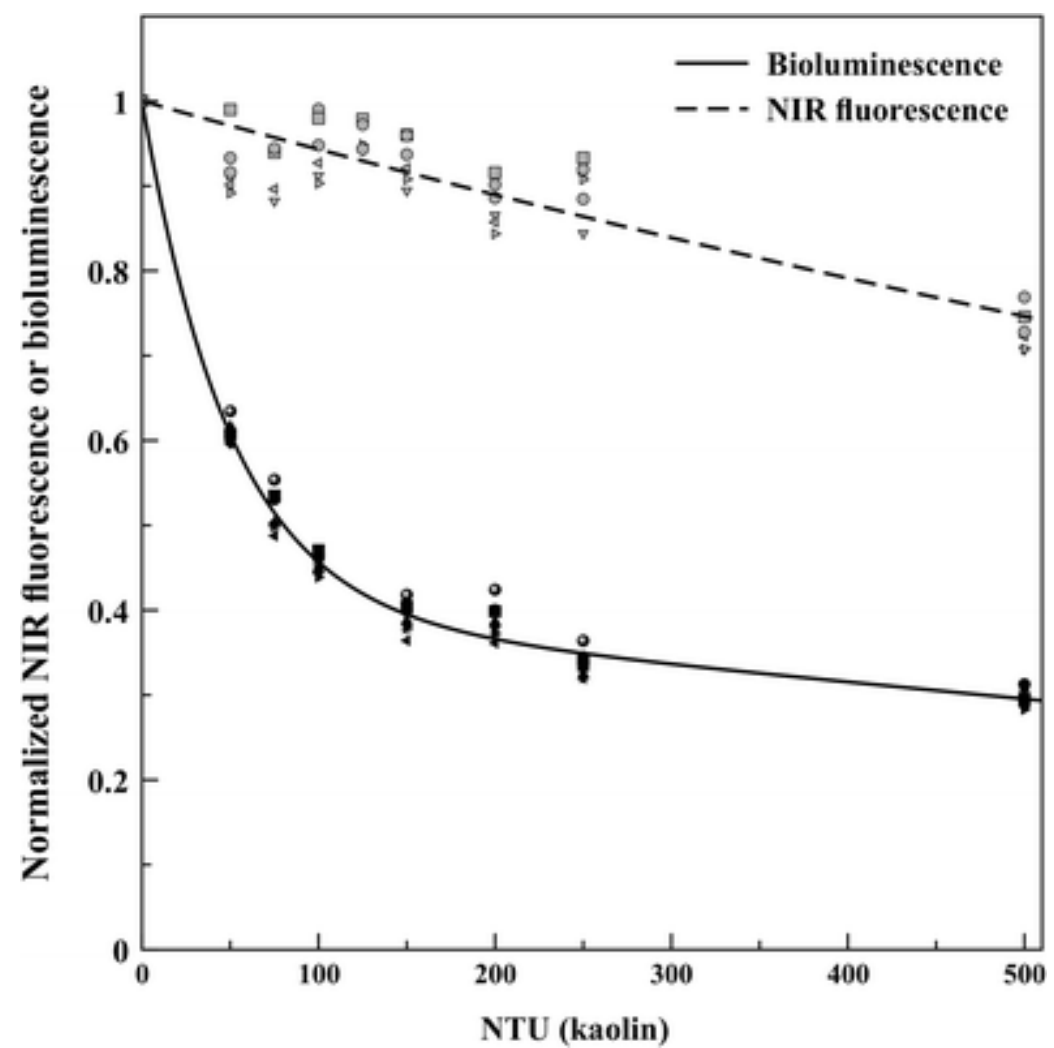

Fig. 8

Light signal attenuation in turbid media. Normalized bioluminescence intensities (rpoD::luxCDABE) and normalized NIR fluorescence intensities (ara::magbphp::hmuO) are indicated with black and gray symbols, respectively

\section{Bacteriophytochrome-based arsenite biosensor}

As evidenced above, NIR fluorescence bacterial biosensors reduce the adverse effects of turbidity in water samples. To go further in the proof-of-concept, we used as a blueprint the bioluminescent arsenite biosensor pArs-lux, replacing the bacterial luciferase by the NIR fluorescent bacteriophytochrome from M. magneticum AMB-1. We engineered a two-plasmid system where the arsenite-inducible $\mathrm{P}_{\text {ars }}$ promoter drives the expression of the heme oxygenase gene $h m u O$ required for biliverdin production, while expression of the apo-bacteriophytochrome structural gene magBphP is controlled on a separate plasmid by the L-arabinose-inducible $\mathrm{P}_{\mathrm{BAD}}$ promoter. We hypothesized that we can achieve a more sensitive measurement with the NIR fluorescent biosensor by separating the expression of the two genes. The rationale behind this assumption is that the production of a single molecule of $\mathrm{HmuO}$ is sufficient to produce several biliverdin molecules ready to be incorporated into a pool of constitutively expressed apobacteriophytochrome MagBphP. This approach was successfully led by Yagur-Kroll and Belkin on a lux-based biosensor with the luciferase structural genes luxAB separated from the substrate production-related genes luxCDE (Yagur-Kroll and Belkin 2010). Figure 9a summarizes the integration over time of the NIR fluorescence emission kinetics for different arsenite concentrations added to the culture together with $1 \% \mathrm{~L}$-arabinose. When L-arabinose is omitted (i.e., no apo-bacteriophytochrome gene expression), we record no fluorescence kinetics (data not shown). When arsenite is added, we observe a dose-dependent increase of the NIR fluorescence signal (Fig. 9a). In the absence of arsenite (Fig. 9a, open squares), we still can measure a NIR fluorescence emission kinetics reminiscent of the bioluminescent signal observed with the luxbased arsenite biosensor; we believe this is probably due to the incomplete binding of the ArsR repressor to the $\mathrm{P}_{\text {ars }}$ promoter. The bacterial growth during the experiment is not significantly affected by the addition of either arsenite or L-arabinose (data not shown) and we chose to represent in Fig. 9a the integration over time of the (fluorescence/OD $600 \mathrm{~nm}$ ) ratio to correct the fluorescence variations due to cellular biomass differences. We then used these ratios to determine a calibration curve for the response of the biosensor to arsenite at different times after arsenite addition (Fig. 9b). In such conditions, we can estimate a detection limit of $0.5 \mu \mathrm{M}$ for arsenite with the NIR-fluorescent biosensor, with a time response to arsenite that is reliable $2 \mathrm{~h}$ 
after contamination, i.e. about two times longer than with the bioluminescent pArs-lux biosensor hosted in E. coli. Owing to its performances in turbid media, the NIR fluorescent reporter gene system is an interesting alternative to other light-emitting biosensors. Further optimization is required to increase the performance of this arsenite biosensor in terms of sensitivity and time response, for instance by selecting a proper host strain and increasing the fluorescence quantum yield of the bacteriophytochrome by site-directed mutagenesis.
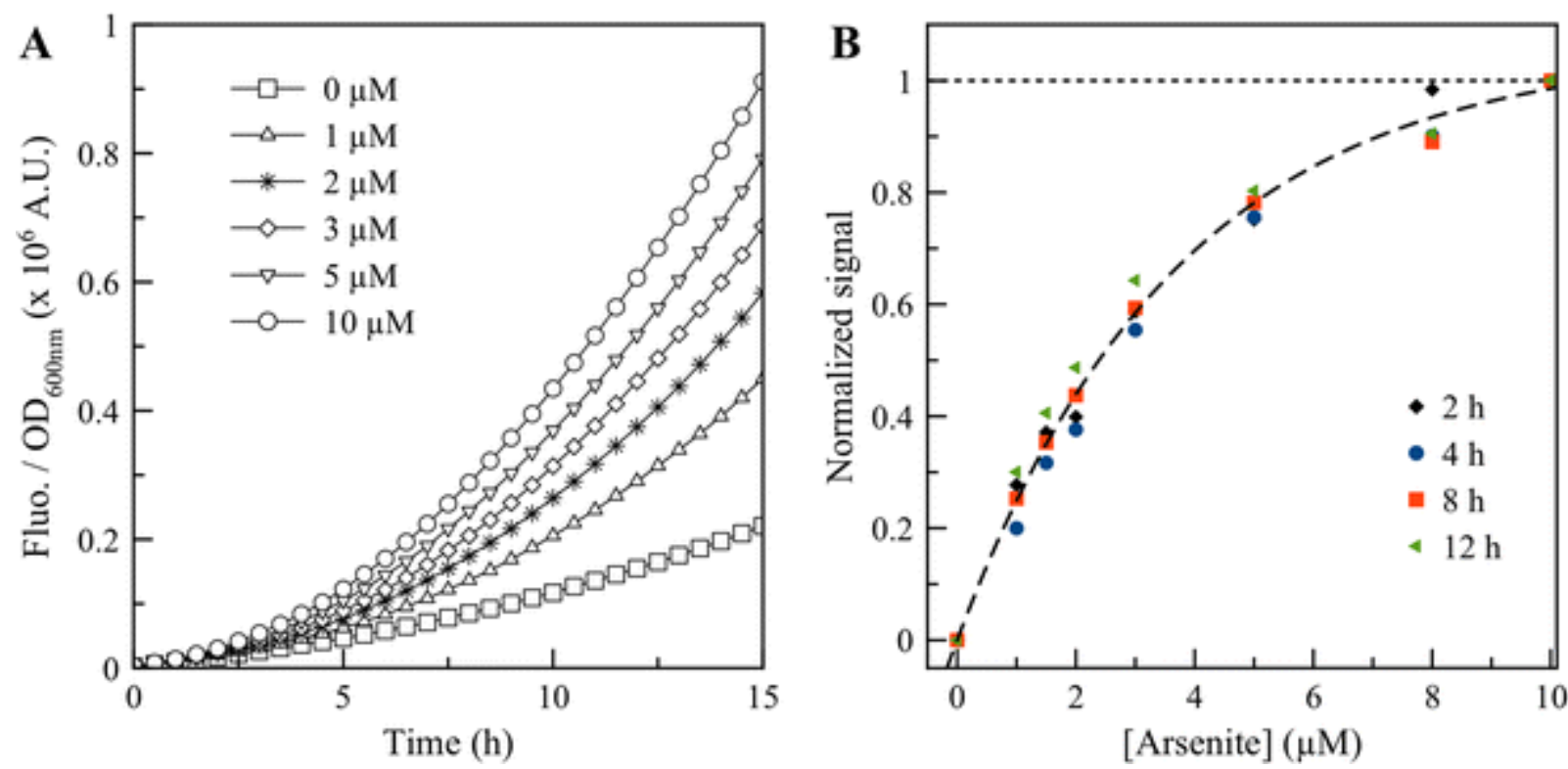

Fig. 9

A NIR fluorescent arsenite biosensor. a Integration over time of the fluorescence/OD $600 \mathrm{~nm}$ ratio kinetics after arsenite addition. $\boldsymbol{b}$ Standard curve for arsenite measured at different times. Data in Panel $\boldsymbol{a}$ are normalized by the value computed at [As] $=10 \mu \mathrm{M}$ after subtraction of the offset value at $0 \mu \mathrm{M}$ arsenite. Fluorescence emission was measured at $755 \mathrm{~nm}$ with excitation set at $685 \mathrm{~nm}$

\section{Conclusions}

At the most basic level, the optimal functioning of bacterial biosensors based on the reporter gene system depends on the careful selection of an operator/regulator pair for efficient translation of the input signal (concentration of a molecule) into a detectable output such as bioluminescence or fluorescence. However, the specificity, the sensitivity, and the time-response of such biosensors do not exclusively rely on transcriptional regulation but are also strongly influenced by the host strain for the same bacterial species. Indeed, for two different lux-based biosensors, we observed in this study important variations of bioluminescence emission levels in five different $E$. coli strains used by the partners in the COMBITOX project. These observations were consistent in both fresh cultures and lyophilized cells. These discrepancies between E. coli strains may be linked either to variations of the promoter efficiency, the regulator stability or modification of the functional behaviors of the reporter proteins in the different yet closely related E. coli strains. Since our approach revealed that it is not possible to find an optimal and universal $E$. coli strain covering all the tested biosensors, biosensor design requires at early stages the empirical screening of host strains. The biosensor response can in a second step be improved by specific genome editing of the selected strain, such as deletion of export pumps or overexpression of specific metal uptake systems as illustrated elsewhere in this special issue (Cayron et al. 2015).

The use of environmental bacterial species as cellular chassis can also represent an interesting alternative to laboratory $E$. coli strains for optimal biodetection under field conditions with complex water samples. In such a context, we transferred our genetic constructs in D. deserti, an environmental strain highly resistant to desiccation; such ability can be exploited for the development of a simpler conservation process than lyophilization. We successfully obtained two functional biosensors hosted in $D$. deserti: (i) the constitutive $\mathrm{P}_{\text {gapdh }}$ promoter was efficiently used 
to induce lux operon expression, resulting in a cell-survival biosensor with a usage for global toxicity similar to the one developed in $E$. coli and described in this special issue (Prévéral et al. 2016); (ii) using $\mathrm{P}_{\text {ars }}$ promoter from E. coli in D. deserti, we were able to detect a concentration as low as $100 \mathrm{nM}$ of arsenite in the medium. The time response of these biosensors is slow (around $10 \mathrm{~h}$ ) and optimizations are required in the future. We showed that air-dried $D$. deserti cells remain responsive to arsenite even after 7 days of storage at room temperature in conditions where E. coli fails to recover. To the best of our knowledge, this study presents the first evidence of a strain from the Deinococcus genus able to produce both the bacterial luciferase and its substrate and to generate bioluminescence. Such genetic modifications result in whole-cell biosensors with potential resistance to DNA-damaging radiation, bestowing robustness to the whole-cell biosensor module of the COMBITOX-like water analyzer exposed to chemical, biological, radiological, or nuclear (CBRN) threats. Owing to its resistance to desiccation, we evidenced that $D$. deserti is a promising candidate to host metal biosensors that can be simply dried for storage while retaining its sensitivity toward the pollutant. The proof-of-concept brought by the prototype arsenite bioluminescent sensor described here paves the way to the development of robust biosensors with improved sensitivity, time response, and shelf life.

In a reporter-based biosensor, the selection of the transducing biological system represents an additional and critical optimization step. Depending on the origin of the water samples, the signal emitted by the reporter gene product can be detected and quantified with varying efficiency; for bioluminescent or fluorescent biosensors, light emission in the visible range of the spectrum is prone to re-absorption in colored water samples or diffusion in turbid media. Fluorescent organic molecules present in environmental samples are also liable to interact with the light emitted by the biosensors, resulting in reduced sensitivity or specificity. The COMBITOX project focuses on the construction of a semi-autonomous inline water analyzer encompassing various biosensors; it is destined to monitor real water networks and the actual physicochemical properties of the water samples prompted us to improve the transducing element of our biosensors. Thanks to its fluorescence in the near infrared spectrum, we tested the bacteriophytochrome from M. magneticum AMB-1 (MagBphP) as an alternative to bacterial luciferase to perform biodetection in turbid samples. We compared the responses of different cell biosensors based on the continuous expression of either the lux operon (promoter $\mathrm{P}_{\mathrm{rpoD}}$ ) or magBphP and its companion heme oxygenase gene (L-arabinose-inducible $\mathrm{P}_{\mathrm{BAD}}$ promoter) and evidenced a drastic loss of the luminescent signal when turbidity is increased, while for bacteriophytochrome-based biosensors, the NIR fluorescent signal remains optimal in a large range of turbidity values. We then designed an arsenite biosensor relying on NIR fluorescence emission and evidenced a detection limit of $0.2 \mu \mathrm{M}$ of arsenite, with a very good reproducibility. Although the time response should be optimized in the future, our NIR-fluorescent reporter gene system represents an interesting alternative to other light-emitting biosensors, notably to transfer laboratory-optimized biosensors into on-field measurements.

\section{Notes}

\section{Acknowledgments}

This work was funded by the French national research agency ANR on the call-for-project ECOTECH (project COMBITOX, ANR-11-ECOT-0009) and also supported by the Centre National de la Recherche Scientifique and the Commissariat à l'Énergie Atomique et aux Énergies Alternatives (program NRBC). We thank all the members of the COMBITOX project for fruitful discussions and interactions. We also thank Dr. Eric Giraud for the kind gift of the РРФ3295 plasmid.

\section{References}

1. Ansaldi M, Bazin I, Cholat P et al (2015) Toward inline multiplex biodetection of metals, bacteria, and toxins in water networks: the COMBITOX project. Environ Sci Pollut Res Int. doi: $10.1007 / \mathrm{s} 11356-015-5582-4$ 
2. Cayron J, Prudent E, Escoffier C et al (2015) Pushing the limits of nickel detection to nanomolar range using a set of engineered bioluminescent Escherichia coli. Environ Sci Pollut Res Int. doi: 10.1007/s11356-015-5580-6

3. de Groot A, Chapon V, Servant P et al (2005) Deinococcus deserti sp. nov., a gamma-radiationtolerant bacterium isolated from the Sahara Desert. Int J Syst Evol Microbiol 55:2441-2446. doi: 10.1099/ijs.0.63717-0

4. de Groot A, Dulermo R, Ortet P et al (2009) Alliance of proteomics and genomics to unravel the specificities of Sahara bacterium Deinococcus deserti. PLoS Genet 5:e1000434. doi: 10.1371/journal.pgen.1000434

5. de Groot A, Roche D, Fernandez B et al (2014) RNA sequencing and proteogenomics reveal the importance of leaderless mRNAs in the radiation-tolerant bacterium Deinococcus deserti. Genome Biol Evol 6:932-948. doi: 10.1093/gbe/evu069

6. Dulermo R, Fochesato S, Blanchard L, de Groot A (2009) Mutagenic lesion bypass and two functionally different RecA proteins in Deinococcus deserti. Mol Microbiol 74:194-208. doi: 10.1111/j.1365-2958.2009.06861.x

7. Giraud E, Verméglio A (2008) Bacteriophytochromes in anoxygenic photosynthetic bacteria. Photosynth Res 97:141-153. doi: 10.1007/s11120-008-9323-0

8. Guzman LM, Belin D, Carson MJ, Beckwith J (1995) Tight regulation, modulation, and highlevel expression by vectors containing the arabinose PBAD promoter. J Bacteriol 177:41214130CrossRefGoogle Scholar

9. Hayashi K, Morooka N, Yamamoto $\mathrm{Y}$ et al (2006) Highly accurate genome sequences of Escherichia coli K-12 strains MG1655 and W3110. Mol Syst Biol 2:2006.0007. doi: $10.1038 / \mathrm{msb} 4100049$

10. Hynninen A, Virta M (2010) Whole-cell bioreporters for the detection of bioavailable metals. Adv Biochem Eng Biotechnol 118:31-63. doi: 10.1007/10_2009_9

11. Magrisso S, Erel Y, Belkin S (2008) Microbial reporters of metal bioavailability. Microb Biotechnol 1:320-330. doi: 10.1111/j.1751-7915.2008.00022.x

12. Matsunaga T, Okamura Y, Fukuda Y et al (2005) Complete genome sequence of the facultative anaerobic magnetotactic bacterium Magnetospirillum sp. strain AMB-1. DNA Res Int J Rapid Publ Rep Genes Genomes 12:157-166. doi: 10.1093/dnares/dsi002

13. Norrander J, Kempe T, Messing J (1983) Construction of improved M13 vectors using oligodeoxynucleotide-directed mutagenesis. Gene 26:101-106

14. Peng Z, Yan Y, Xu Y et al (2010) Improvement of an E. coli bioreporter for monitoring trace amounts of phenol by deletion of the inducible $\sigma 54$-dependent promoter. Biotechnol Lett 32:1265-1270. doi: 10.1007/s10529-010-0317-6

15. Prévéral S, Brutesco C, Descamps ECT et al (2016) A bioluminescent arsenite biosensor designed for inline water analyzer. Environ Sci Pollut Res Int. doi: 10.1007/s11356-015-6000-7r

16. Rose RE (1988) The nucleotide sequence of pACYC184. Nucleic Acids Res 16:355

17. Sharrock RA (2008) The phytochrome red/far-red photoreceptor superfamily. Genome Biol 9:230. doi: $10.1186 / \mathrm{gb}-2008-9-8-230$

18. Shu X, Royant A, Lin MZ et al (2009) Mammalian expression of infrared fluorescent proteins engineered from a bacterial phytochrome. Science 324:804-807. doi: 10.1126/science.1168683 
19. Sun J-Z, Peter Kingori G, Si R-W et al (2015) Microbial fuel cell-based biosensors for environmental monitoring: a review. Water Sci Technol J Int Assoc Water Pollut Res 71:801809. doi: $10.2166 /$ wst.2015.035

20. Vallenet D, Labarre L, Rouy $Z$ et al (2006) MaGe: a microbial genome annotation system supported by synteny results. Nucleic Acids Res 34:53-65. doi: 10.1093/nar/gkj406

21. Vinay M, Franche N, Grégori G et al (2015) Phage-based fluorescent biosensor prototypes to specifically detect enteric bacteria such as E. coli and Salmonella enterica Typhimurium. PLoS One 10:e0131466. doi: 10.1371/journal.pone.0131466

22. Winson MK, Swift S, Hill PJ et al (1998) Engineering the luxCDABE genes from Photorhabdus luminescens to provide a bioluminescent reporter for constitutive and promoter probe plasmids and mini-Tn5 constructs. FEMS Microbiol Lett 163:193-202

23. Xiong A-S, Peng R-H, Zhuang J et al (2012) Advances in directed molecular evolution of reporter genes. Crit Rev Biotechnol 32:133-142. doi: 10.3109/07388551.2011.593503

24. Xu T, Close DM, Sayler GS, Ripp S (2013) Genetically modified whole-cell bioreporters for environmental assessment. Ecol Indic 28:125-141. doi: 10.1016/j.ecolind.2012.01.020

25. Yagur-Kroll S, Belkin S (2010) Upgrading bioluminescent bacterial bioreporter performance by splitting the lux operon. Anal Bioanal Chem 400:1071-1082. doi: 10.1007/s00216-010-4266-7

26. Yagur-Kroll S, Belkin S (2014) Molecular manipulations for enhancing luminescent bioreporters performance in the detection of toxic chemicals. Adv Biochem Eng Biotechnol 145:137-149. doi: 10.1007/978-3-662-43619-6_4 